\title{
Individual Taxpayers Compliance in Policy of Post Tax Amnesty Program: Phenomenology Study
}

\author{
Lanny Kusumawati $^{1}$ and Tjiptohadi Sawarjuwono ${ }^{2}$ \\ ${ }^{1}$ Master of Accounting Program, Faculty of Economic and Business Airlangga University \\ ${ }^{2}$ Lectur of Faculty of Economic and Business Airlangga University \\ Surabaya \\ Indonesia
}

\begin{abstract}
This study aims to assess the compliance of individual taxpayers after the tax amnesty program policy and its benefits for taxpayers are for the State. This research is qualitative research with phenomenology method. Qualitatively by exploring the values of the experience of human life, the aim is to discover the essence of the experience. Phenomenology method, namely by looking at phenomena, reality and experience, by digging data to find things that are fundamental and important, so as to obtain a picture of life directly from people who experience it. The method of data collection used is through interviews. This study uses Theory of Planned Behavior (TPB) to examine the reaction of taxpayers after tax amnesty, and Theory of Compliance (Compliance Theory) to examine taxpayer compliance with the fulfillment of the obligation to pay taxes after tax amnesty. The results of this study prove that out of 3 (three) taxpayers as respondents, have responded positively to the tax amnesty policy even though each respondent has different motivations. Respondents became obedient after the tax amnesty program policy because they were aware that the purpose of the tax amnesty is as a government effort to improve economic conditions, development and reduce unemployment, reduce poverty and improve inequality.
\end{abstract}

Key Words: Compliance, Tax Amnesty, Theory of Planned Behavior(TPB), Theory of Compliance.

\section{INTRODUCTION}

This study examines the reaction of taxpayers post tax amnesty and personal taxpayers compliance. This is important to be the focus and main objective of the Directorate General of Taxation, because it is related to improving the consistency and compliance with tax rules.

The number of taxpayers is not obedient, so that in various ways he avoids taxes in ways that are not permissible according to law. An attempt to realize an increase in state revenues for development really can be realized is from the tax sector, by exploring sources of funds originating from within the country.

Brotodihardjo (2012: 8), James and Beck (1993: 53-60), said: "The amnesty program is advertised as the last opportunity for naughty taxpayers to comply with tax laws before civil and criminal penalties for non-compliance are increased".

Choiruman (2004) argues that to improve taxpayers compliance, it should be done by the Government, because there are many factors that influence WP compliance from the Government, as much as possible the potential tax will be explored continuously by the Government, also increasing WP compliance.

Tax amnesty is also seen as the beginning of tax reform which is law enforcement in minimizing negative tax avoidance. This research is based on aspects of WP behavior after taking advantage of opportunities for tax amnesty implemented in Indonesia.

The government is time to immediately accelerate the process of embodying good governance. In order to improve WP compliance, the Government needs to transparently explain to the public on a regular basis about the use of money from the tax sector. WP awareness must of course begin with socialization of tax regulations, especially taxation procedures and obligations, as well as sanctions. WP must be made obedient to their obligations as good citizens.

Tax amnesty is an opportunity to free the taxpayers from payment of tax payable and tax audits, within a certain period of time, through stages with different ransom values. 
James Alm \& William Beck (1993: 53) say: "Governments from all over the world are increasingly turning to tax amnesty as part of their fiscal program".

The tax amnesty program policy is intended to measure the strategic performance and reaction of taxpayers to compliance as taxpayers. Compliance with tax payments is strongly influenced by scientific behavior or scientific manner. According to Hofstedt and Kinard in E. Michael Bamber, (1993: 2), said:

The study of the behavior of accountants and non accountants as they are influenced by accounting functions and reports.

This study will discuss behavior or attitude after the implementation of tax amnesty in terms of planned behavior theory, compliance theory, and the theory of justice. Darmawan (2016) found that in terms of value, the tax amnesty program aims to provide justice for taxpayers, with the elimination of tax payable should not be subject to tax administration sanctions and criminal sanctions in the field of taxation, by disclosing assets owned and paying ransoms.

\subsection{Research Purposes}

The research was held aimed at answering research questions on:

1. The attitude and motivation of individual taxpayer is to follow the tax amnesty program policy

2. Compliance with individual taxpayers after tax amnesty

\subsection{Benefits of Research.}

This research is expected to have the benefit of:

\subsubsection{Theoretical benefits}

Adding the treasury of knowledge related to taxation policies, both in the field of tax extensification and intensification, namely tax amnesty in relation to taxpayer compliance.

\subsubsection{Practical benefits}

Provide input for educational institutions, for the public / WP, and for researchers to comply with tax policies carried out by the Government to the fullest.

\subsubsection{Scope of Research.}

The scope of this study is limited only to the study of research questions. This is done so that the discussion does not expand, so the scope is limited to the compliance of taxpayers after the tax amnesty program through behavioral studies (behavioral sciences), and compliance theory, to measure the taxpayers awareness level in paying their tax obligations.

\section{STUDY OF LITERATURE}

\subsection{Tax Amnesty}

The slogan in the TA program in 2016 is: expressing redemption and relief. WP is very enthusiastic in participating in the TA program because the WP receives many facilities and various benefits, namely administrative sanctions and criminal sanctions, as long as the SKP has not been issued, especially the PPh and VAT payable.

This was proven by WP's reaction after the TA program policy stated that they were very satisfied, taxpayers began to orderly report SPPT, many new registrants as taxpayers, namely to obtain NPWP. The fact is that there is a significant increase in state revenues.

\subsection{Theory of Planned Behavior (TPB)}

According to Ajzen \& Fisbein (1975 \& 1991), and Mustikasari (2007) there are three (3) types of belief theories that are distinguished by TPB, namely

1. Belief (belief), namely behavioral belief,

2. Normative belief, and;

3. Control belief, where it is related to construction of attitude, subjective norms, and control of perceived behavior (perceived behavior control) 
To integrate all beliefs about behavior, criteria as a measure are attitude. This attitude will evaluate the person, so that it has value on expected social behavior, namely subjective norms and self-efficacy with perceived behavior control. Each has an important place in social research and behavior.

Of the three factors, it should be noted, especially the last stage, is behavior. This behavior must also be based on values, ethics and morals. That is, the tax authorities need to have a plan to treat the WP in such a way that WP obeys to pay taxes as an obligation, for example by simplifying the tax payment system, not complicated, good service, providing tax information.

\section{PICTURE : 1}

\section{Model Theory of Reasoned Action}

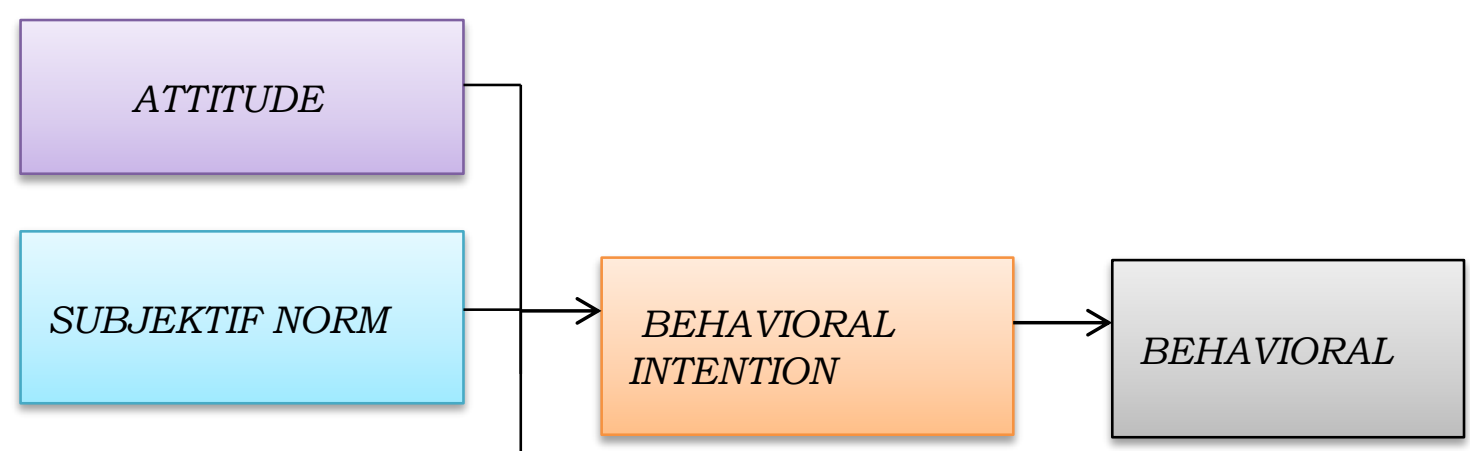

\section{PERCEIVED BEHAVIOR} CONTROL

\section{Source : Ajzen (1980)}

The combination of behavioral belief, normative belief and belief control in following the tax amnesty must be based on behavior, values, ethics and morals. This means that the tax authorities need to have a plan to complete their duties and tax obligations in accordance with the TA Law and implementing regulations.

\subsubsection{Attitude}

Attitude is evaluative disclosure - either unsatisfactory or satisfying, regarding objects, people or events. According to Robbins and Judge (2015: 43-44), this attitude consists of several components, namely:

(1) cognitive component, namely movement by using knowledge or reason that produces an attitude towards an action taken;

(2) affective component that is feeling will influence emotional attitude and reflect statement, finally produce behavior;

(3) Psychomotoric component, which behaves in such a way as an action as an attitude, which will produce a value as a response to behavior.

Jung (2012) defines attitude as a reaction to emotions to act, this action produces behavior. The emergence of attitude is spontaneous between conscious and unconscious.

This attitude expresses feelings that present likes or dislikes (positive, negative or neutral). Attitudes arise with various judgments, which are developed by assessors. Attitudes can change due to surrounding or environmental influences or persuasion.

Fishbein and Ajzen (1988), based on the Theory of Reasond Action, states that the results of the study are 3 (three) things:

(1) Taking a decision is influenced by a specific / specific attitude towards something, not influenced by general attitude;

(2) Specific / specific attitudes not only affect behavior, but also influenced by subjective norms, namely a person's belief in what others want, how he should behave;

(3) An intention or intention to behave will be formed together with subjective norms. 
Leon Festinger in Robbins (2015: 45) says that any incompatibility felt by individuals is a behavioral attitude that illustrates cognitive dissonance, between two or more attitudes or between behavior and attitudes. Festinger said that individuals will try to eliminate all forms of inconsistency due to inconvenience.

\section{PICTURE : 2}

\section{Components - Components of an Attitude}

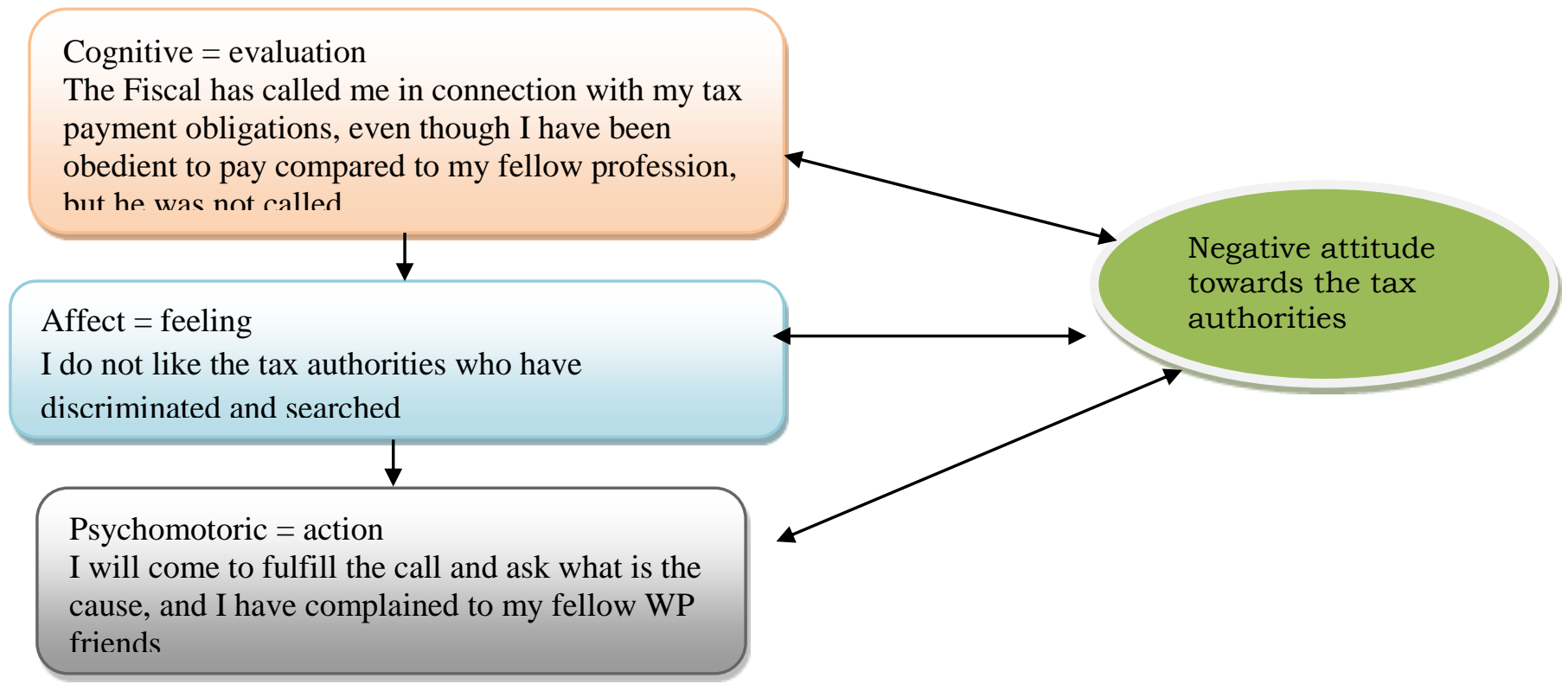

Motivation is always associated with the needs of human life. A Maslow (1943) suggested that there are basic needs for humans, to high needs, which are based on 5 needs based on the hierarchy. It is this human need that ultimately impacts on taxpayers payments. If the taxpayer needs are high, it is difficult for the taxpayer to comply with its obligation to pay taxes, because the taxpayer tends to prioritize its needs. This is human selfishness in general.

Vroom (1964), said that there are 3 (three) components about the high and low of one's motivation, namely: hope, means, and reality. In this case, if it is associated with a post-tax amnesty program, taxpayer certainly considers the advantages of joining the tax amnesty program, what to expect after participating in the tax amnesty program, what behaviors are needed to join the tax amnesty program, what responses will be received by taxpayer, for example there are positive feelings / negative, neutral. Then the motivation is still necessary and must be continuously carried out by the Government even though the tax amnesty program has ended. This means that the taxpayer is conditioned in such a way that the taxpayer is motivated to comply with its obligations after tax amnesty, so that the Government's objectives are achieved, as well as the expectation to meet the minimum target is approaching the target. With continuous motivation, the taxpayer will obey paying taxes.

\subsubsection{Value}

Klandersman (1984) states that a person's behavior will produce something, the higher the expected value, the higher the desire to manifest certain behaviors. Means that a person's behavior is a function of the value (value) of the results expected from an action, "individual's behavior is a function of the value of expected outcomes."

Keller has developed a behavior theory that originally consisted of 2 (two) components of values and expectations. Value is the goal to be achieved, while the hope to achieve that goal. Then the behavior theory becomes 4 (four) components, namely attention, relevance, confidence and satisfaction.

Expected value after conducting an attitude and motivation study, the researcher can assess the expected influence or impact. If it is associated with taxpayer compliance, the researcher argues that the value adopted and evaluation of the tax amnesty program is a person's attitude towards taxpayer treatment. The attitude of the taxpayer towards behavior depends on the tax amnesty policy program and its implementation is an assumption of value, which brings hope for the Government to improve compliance in making tax payments consciously. 


\subsubsection{Compliance Theory.}

According to Tahar and Rachman (2014), that for the government and the people as taxpayers to fulfill all tax liability activities and implement their tax rights, compliance with taxation is also required which is also a responsibility to the State.

Rahayu (2010) said that if the taxpayer fulfills all tax obligations, it means that the taxpayer has obeyed and obeyed taxation rights.

Erard and Feinstin interpret taxpayer compliance using psychological theory, namely as guilt and shame, perceptions of taxpayer for fairness and justice tax-free they bear and the influence of satisfaction with government services.

Mardiasmo (2011) states that taxpayer compliance can be divided into 2 in general, namely:

(1) Formal compliance

Formal compliance reflects the fulfillment of the obligation to deposit and report taxes in accordance with a predetermined schedule.

(2) Material compliance

The substance aspect is highlighted, namely the amount of tax payment is correct and correct, there is no data manipulation.

Thus the taxpayer has complied with 2 things, namely in terms of formality and substance. This is corroborated by the opinion of Kelman, who said that a good taxpayer hopes to receive influence, the tax authorities react by showing an attitude to the WP, he has obeyed.

\subsubsection{Justice Theory.}

Mardiasmo (2011) said that tax collection must meet and comply with legal objectives, and laws, so that tax collection does not cause obstacles or resistance, in order to achieve justice.

Mill (1957: 10) on Karen Lebacqz (2015: said that the subject of utilitarian thought is very simple, that is to produce the greatest good for the right, because ideas are one way for humans to issue ethical decisions.

Rescher (1968: 25), in Lebacqz (2015: 35) a new action is considered right and fair when distributed / distributed equally, known as distributive justice, lies in giving to the community according to legal claims.

This theory of justice greatly underlies tax collection, without justice, tax collection can be considered as a seizure of people's property, so that the taxpayer pays taxes, but the Government must provide benefits that can be enjoyed by taxpayer, so that it is fair.

\section{RESEARCH METHODS}

\subsection{Types of research.}

This research is categorized as qualitative, with an interpretive approach, trying to explore the reactions of individual taxpayer after tax amnesty through collecting data with various sources, namely literature studies, interviews, and reporting in the form of descriptions.

Based on the ability of understanding the researcher, to express the intent contained in the object of his research, through interpretive descriptive research to review the problem with clear descriptions.

A type of research that tries to describe or recount the opinions or views that exist in the object of research on tax amnesty program policies makes WP obedient to the payment of tax obligations.

Burell and Morgan (1979: 20) say, "interpretive as a paradigm that has the nature to understand and explain the social world from the conditions of the results of social processes". The method used is phenomenology, namely by looking at phenomena, reality and experience, by digging data to find things that are fundamental and important.

Kuswarno (2009: 36), the nature of qualitative research is to explore the values of the experience of human life, the purpose of which is to discover the essence of experience in essence. Thus the data obtained will reveal and understand human behavior, and obtain a picture of life directly from people who experience through interviews, both formal and informal.

By looking at experience and behavior is an integral and comprehensive part of the subject and object under study. Phenomenology methods will try to express and understand the reality of research based on the perspective of research subjects. 


\subsection{Place and Time of Research}

This research was conducted by making an appointment to the informant at the Notary Office, Jalan Pahlawan Number $41 \mathrm{C}$ Surabaya. The researcher conducted an interview with the informant. This informant is a research client. The informant taken was the taxpayer who had made a statement of assets, revealing all the assets owned and / or informants who had made nominee statements on assets in the form of fixed objects.

The researcher took 3 (three) informants to be interviewed, because the statement of wealth that was made was very much the wealth that was disclosed compared to what had been reported, so that the researcher was very interested to know the background of participating in the tax amnesty. Of course there are supporting documents related to tax amnesty regulations. This interview takes around 20 minutes per taxpayer, to answer the same 5 (five) questions.

\subsection{Data Sources}

Primary data and secondary data are data used in this study. Data originating directly from the source of data specifically collected that relates to the research question is primary data.

Primary data is library research, among others, previous research, letters of statement of disclosure of assets, related tax regulations, and nominee statement letters.

Interviews are secondary data carried out to three individual taxpayers participating in the tax amnesty program, they are from various professions, namely businessman A, Notary B and Lecturer C. Of the three informants as taxpayers get different answers to questions that same.

The reason the researchers chose the three informants was that they were directly related to the situation under study, namely the tax amnesty program policy, and three taxpayers as informants needed to be interviewed, because they were interested in the tax amnesty, where they each revealed assets that extraordinary, which has never been revealed, so impressed when this is the most back opportunity to be honest.

\subsection{Data collection technique}

This research began with a library study, in conducting this data collection, researchers have prepared various regulations regarding tax amnesty, along with implementing regulations, and relevant theories to examine taxpayer behavior. After that, the researcher conducted a field study by looking for the right informants to be interviewed.

The interviews were conducted with three individual taxpayers who participated in the tax amnesty program, they were from various professions, namely businessman A, Notary B and Lecturer C. Of the three informants as taxpayers this received different answers to the same question.

The reason the researchers chose the three informants was that they were directly related to the situation under study, namely the tax amnesty program policy, and three taxpayers as informants needed to be interviewed, because they were interested in the tax amnesty, where they each revealed assets that extraordinary, which has never been revealed, so impressed when this is the most back opportunity to be honest.

In data processing methods, the social sciences in general are influenced by 2 (two) perspectives, namely positivist flow and phenomenology. This indicates that a qualitative approach can be used for data processing. In this case, researchers use a phenomenological perspective, namely:

TABEL 3.4.1. SUBSTANTIAL PERSPECTIVE FLOW

\begin{tabular}{|l|l|}
\hline SUBSTANTIAL PERSPECTIVE FLOW & PHENOMENOLOGY \\
\hline Research focus & $\begin{array}{l}\text { Understanding human behavior from the point of view of the person } \\
\text { concerned is the target }\end{array}$ \\
\hline How to collect data & $\begin{array}{l}\text { Using observations on relevant subjects and objects, perhaps also } \\
\text { interviewing clients as individual taxpayers. }\end{array}$ \\
\hline Data Processing Approach & Processing qualitative data aims to understand the symptoms under study. \\
\hline
\end{tabular}


Descriptive analysis is the result of the procedure of research with a qualitative approach, which is stated by researchers as the object of research that is made in writing or verbally, and is real behavior.

\subsection{Analysis technique.}

Indriantoro and Supomo (2010: 28) that the efforts made in analyzing qualitative data are by working with data, organizing data, sorting it out, into manageable units, finding and finding patterns, finding what is important and what is learned and decide what can be recorded as input.

The way to analyze the data begins with a process by examining all available data from various sources, reducing data by making abstractions, arranging it into units, categorizing it by making coding, and finally checking the validity of the data.

The analysis was carried out on the data obtained from the research that played a role / interview contained in the relationship between the client/Trader, Notary and Lecturer as an informant

Interviews were conducted focusing on the questions that had been chosen prepared by the researcher. To deepen the data that has been found through contrasting questions, the results of the study are used to conduct a theme analysis, which is a procedure for understanding holistically the object under study.

Sugiyono (2010) states, that the process of systematically searching for and compiling data obtained from interviews, field notes and documentation, by organizing data into categories, describing into units, synthesizing, arranging into patterns, choosing which what is important and which will be studied, and make conclusions, is referred to as data analysis. Thus it is easily understood by oneself and by others.

\section{DISCUSSION OF RESEARCH RESULTS}

\subsection{Research framework.}

A framework written in this study can be summarized as follows:

\section{PICTURE : 3}

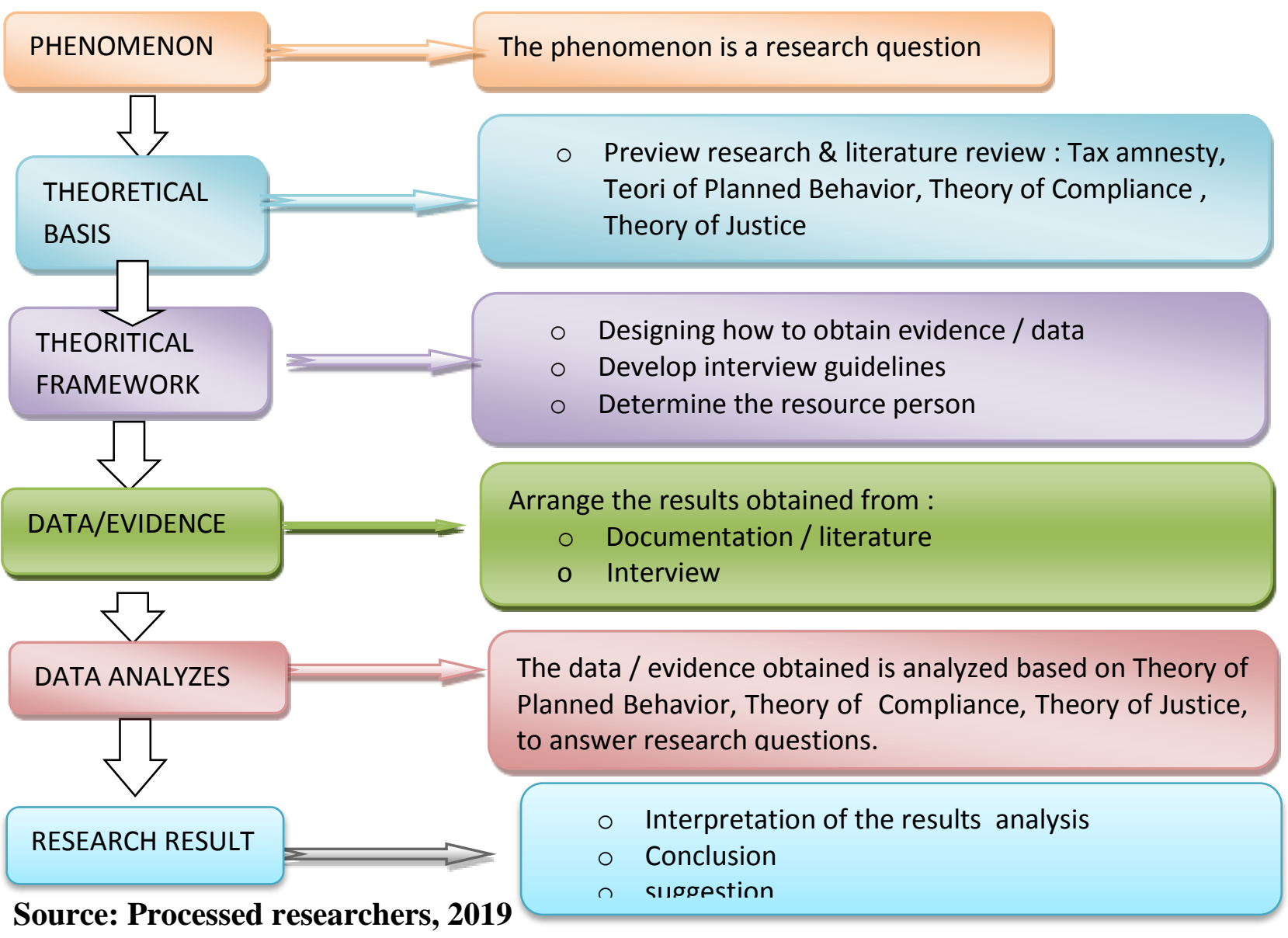




\subsection{Research result.}

Explanation in the previous chapters, and the results of interviews from several informants from different professions, the answer is very positive, that TA is very helpful to ease the burden of WP, especially those who have been dishonest in reporting their assets and profits, so that taxes paid are very small once not comparable to the assets owned and profits obtained. The majority of WP's reactions welcomed the TA program and were very pleased with the TA program policy.

Ngadiman and Huslin (2015) said that TA Policy is expected to increase the awareness of WPs to obediently fulfill their tax obligations, improve taxation databases in Indonesia, and simultaneously reduce tax leakage.

The purpose of this tax amnesty policy is to utilize all existing conditions, factors and resources, so that organizational goals can be achieved and succeeded. This is one of the manifestations of the modernization of organizational strategies seen as tactics, attitudes of views and actions.

The public reaction, especially WP after TA was very enthusiastic and satisfied, WP began to be careful in dealing with the affairs of its tax report, trying to be orderly and honest. This needs continuous guidance by the tax authorities, so that WPs become more aware of their obligations, so compliance will occur.

Motivation to pay taxes can arise from within or outside the individual, must be honest, report their obligations and desire to pay taxes. So, WP is a potential power that exists in itself to pay taxes. While motivation from outside WP is the encouragement of tax officials, work environment, friends or relatives who encourage them to pay taxes.

\subsection{Discussion}

\subsubsection{The attitude and behavior of taxpayers after the implementation of the tax amnesty}

Istighfarin and Fidiana (2018) examined that the TA policy was estimated by the Government, at the initial stage, potentially contributing Rp. 100 trillion.

Brodjonegoro (2016), the expected target of the TA program policy should have a tremendous positive impact on the structure of the APBN in the future. This has been proven by many countries, as experience, TA is very supportive of state finances, for example South Korea, South Africa and India are examples of countries that have successfully implemented TA policies. But apparently, the target was not reached

Darussalam (2016) explains that there are several objectives for TA, namely:

(1) in the short term, it will increase tax revenues

(2) in the future, it is predicted that WP compliance will increase;

(3) motivating the withdrawal of existing money abroad to be brought

into Indonesia / repatriation of capital and assets;

(4) using a new taxation system.

There is no discourse or discrimination issue between an orderly WP and tax evaders. So TA is a national reconciliation to eliminate WP's past mistakes, this is in line with Darussalam's (2014) opinion. Thus the clarity of the TA program really has legal certainty.

To build voluntary compliance for WPs in carrying out their tax obligations, of course it needs to be fair and comfortable for WP, so that the level of compliance of the WP will increase, and the WP will be transparent in reporting income and allocating taxes to be paid.

Internal and external conditions of WP, are very influenced by needs, so that attitudes and motivation have an important role for WP to obey. WP will assess and fully consider the tax awareness that is its obligation, so that the WP will obey to carry out its obligations after / after TA. If the internal condition of $\mathrm{W}$ is the number of needs that must be met, of course the WP can be reduced in compliance, considering there are still internal needs that must be fulfilled, so if the WP still has more important external needs, it is likely that the WP will reduce the value of tax deposits by providing reports dishonest. Then the WP motivation needs to be addressed by the tax authorities continuously, so that the WP does not prioritize personal needs both internally and externally.

The implementation of TA in Indonesia if it is related to the theory expressed by Ajzen (1988) in Robbins and Judge (2015), it can be found that:

(1) Cognitive component. 
This component focuses on basic knowledge and information owned by WP to react to it.

The basic knowledge in question is concerning the rights and obligations of the WP about KUP, starting with the simplest, namely registering as a WP by obtaining a tax ID, etc., so that the WP will have ethical and moral attitudes and behaviors, and have a sense of responsibility to show their awareness as a good Indonesian citizen

In self WP, certain beliefs about attitudes and behavior will be formed, and gradually the WP will form values of compliance with the payment of taxes, which will contribute to the development of the State.

\section{(2) Affective component.}

This component is evaluative in nature, by self-reflection on the values that are owned, a sense of pleasure, comfort, fairness, which has been owned post-TA, so that the WP will think clearly about the conditions associated with the obligation to pay taxes. This will form a sense of responsibility to the State as a good WP.

\section{(3) Psychomotor components.}

Taxpayer has prepared itself based on its awareness to comply with the fulfillment of tax payment obligations after tax amnesty, so that the taxpayer really understands eneral provisions of taxation, with a self assessment system that has been implemented in Indonesia.

Research by Istighfarin and Fidiana (2018), that the motivation of WPs to participate in tax amnesty is primarily to get forgiveness for their mistakes as WP, or pay but lack, manipulate, cheat, and so on.

This is natural for taxpayer as a business actor. Taxpayer motivation has brought very rational attitudes and behavior. This mathematical mindset has been utilized by the majority of taxpayer, rather than having to pay high taxes, it is better to join tax amnesty, with low tariffs as ransom, all taxpayer mistakes regarding tax are forgiven.

\subsubsection{Post tax amnesty conditions in terms of compliance theory}

Formally and materially, the taxpayer has fulfilled its obligations in paying taxes, so this attitude of compliance is based on motivation and strategy. Then the tax authorities must always motivate the taxpayer, so that compliance does not stop, but continuously and continuously. The taxation system of course must always be reviewed and made simple, socialized to the taxpayer.

Nowak (2004), taxpayer compliance is reflected in the number of taxpayers who report annual tax returns, the number of new registrants as taxpayers, the value / amount of income / state income from the tax sector, all of which are guided by general provisions of taxation.

\subsubsection{Post tax amnesty conditions from the side of Justice theory}

Sa'adah (2017) argues, that tax amnesty policy has 2 (two) different points of view, on the one hand, the WP says that tax amnesty is not fair, because the orderly taxpayers pay taxes in real terms, the State does not provide rewards, while in one On the other hand, taxpayers who make fatal mistakes are related to reporting and paying taxes that are not properly received forgiveness by paying a ransom whose value is small compared to the mistakes made and detrimental to the State for years. Rosdiana (2012) in line with Sa'adah's opinion, he said that there was special treatment contained in the tax amnesty policy program, for taxpayers who were fraudulent and disobedient who had harmed the State, but were forgiven.

However, the objective of the Government in issuing a tax amnesty policy program is to obtain benefits, not related and considered to injure justice towards the obedient taxpayer, but must be taken in terms of benefits.

From the explanation above, it raises a new hope for both the Government and WP, namely the existence of value, as has been revealed by Klandersman (1984) saying: "Individual's behavior is a function of the value of expected outcomes". So the value function is the result of a person's behavior and is a result expected from an action. After this tax amnesty, it is expected that WP behavior will be compliant and no longer repeat the same mistakes as before the tax amnesty program.

The following is a summary of the discussion, which is described as follows: 
PICTURE : 4

\section{PHENOMENON:}

1. Many tax evaders;

2. State income from the Tax sector tends to decrease;

3. Implementation of tax payments is too bureaucratic

4. Low WP awareness

5. Service Quality of the Low Fiscal;

6. Lack of socialization of regulations

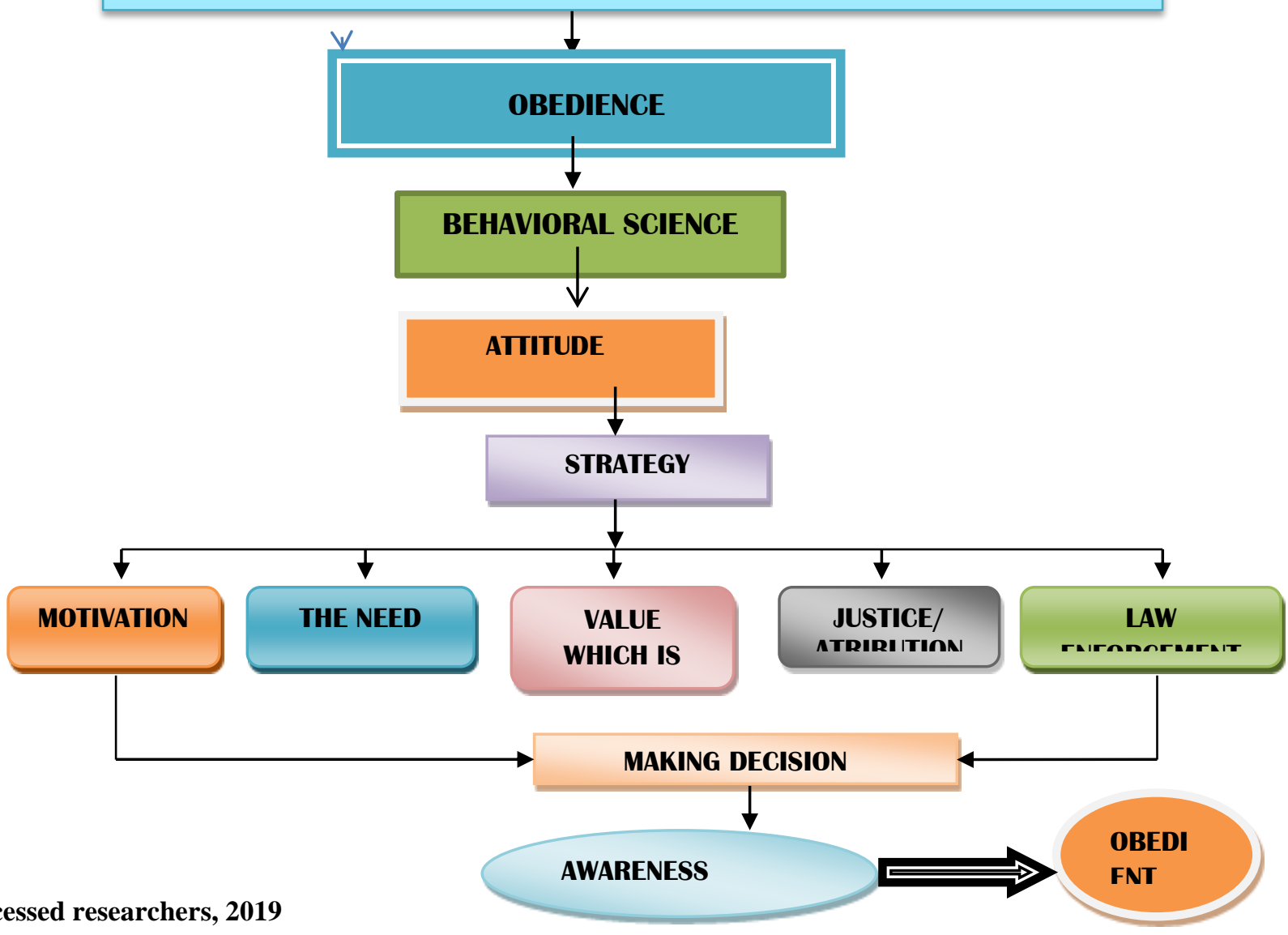

Source: Processed researchers, 2019

Harry Graham Balter (2003: 75), said that to reduce the tax burden or even eliminate tax debt, as one way of avoiding taxation can be allowed as long as it does not violate applicable tax laws and does not cause legal consequences that harm the State.

Awareness is the main key for WP to be obedient, without WP awareness, it is difficult to make WP obedient. WP compliance is a contribution to the State for development, which will have an impact to improve the lives of the people and realize prosperity and prosperity for the people of Indonesia. 


\section{PICTURE : 5}

\section{Framework for Discussion on Post Tax Amnesty Compliance Attitudes}

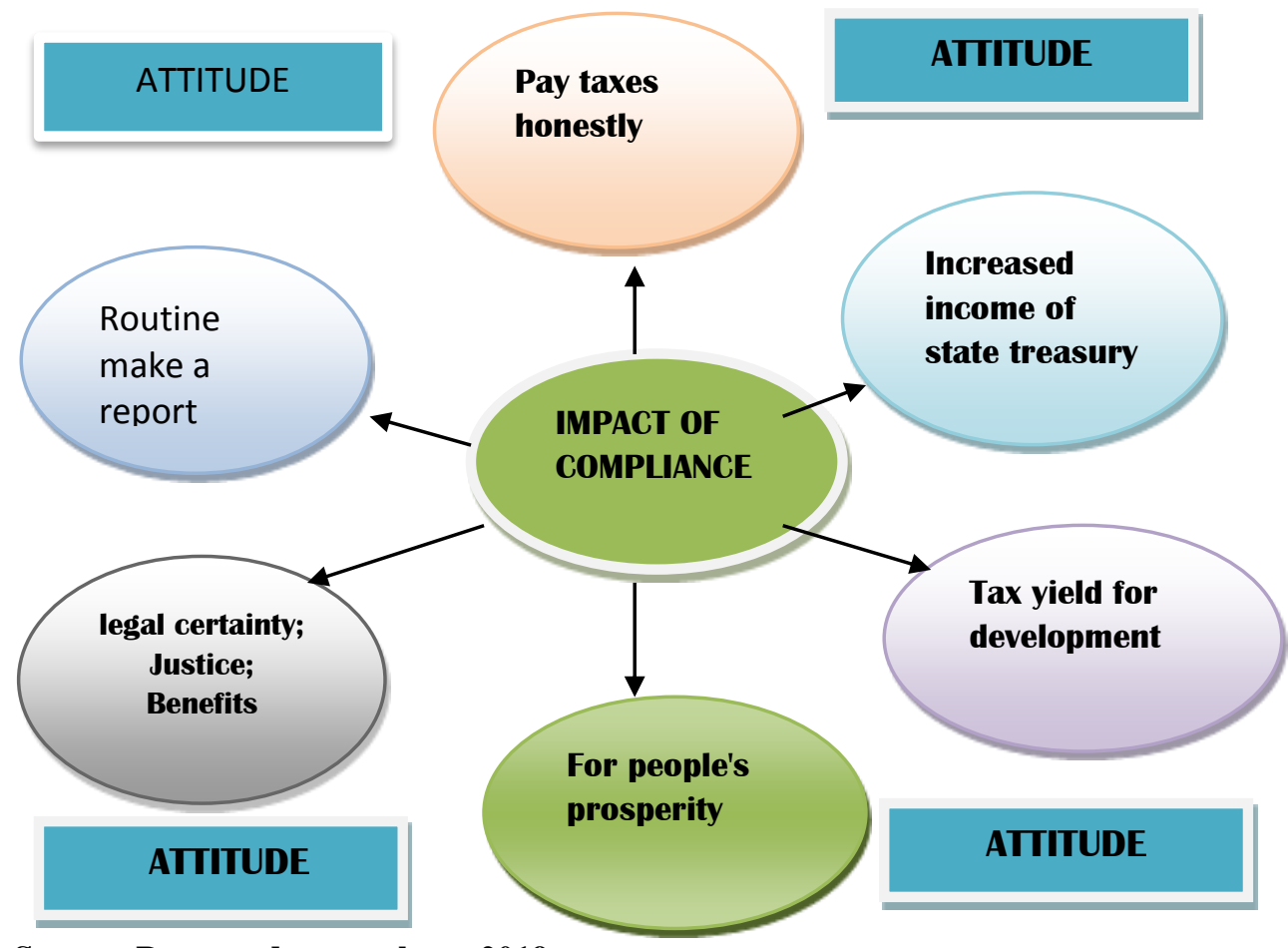

Source: Processed researchers, 2019

\section{CONCLUSIONS AND SUGGESTIONS}

\subsection{Conclusions}

Based on what has been described in the previous chapters, a conclusion can be drawn:

(1) The reaction of the majority of personal taxpayers welcomed the tax amnesty program policy, they began to arrange annual bookkeeping and tax reports according to the facts, no longer making double books. taxpayer responses and reactions are very positive towards the tax amnesty program. This is in the view of business people, on average, saying that tax amnesty has great benefits for the taxpayer and for the State, because from the taxpayer side, they have benefited, only paying a very small ransom, then all fines and interest are written off, no longer being examined for the last 5 years report, whereas for the State, there is income from taxpayer that can be used to finance the State expenditure budget $(A P B N)$, thus tax amnesty has a great value for taxpayer, so there is no need to doubt. So the post-tax amnesty taxpayer reaction is:

a. In terms of components forming attitudes and behaviors, namely the components of cognitive, affective and psychomotor, the taxpayer if he has an understanding of the conduct of tax amnesty carried out in Indonesia, will lead to long-term tax compliance.

b. In terms of compliance theory, taxpayers compliance in Indonesia is still low, as seen from the number of indebted notice reports only around $40 \%$ with a small income, so that paid taxes are also small, while $35 \%$ make indebted notice reports but nothing because there are no benefits. The remaining $25 \%$ have no reports.

c. In terms of the theory of justice, justice is very relative, depending on the perspective of each taxpayer. What's important between taxpayer and the State is mutually beneficial and has benefits for both.

(2) After the tax amnesty program has made taxpayers awareness, it has been proven to have made compliance, namely:

a. applicants as new taxpayers increase, by registering an tax ID number,

b. Annual indebted notice report is more orderly;

c. The income of tax money to the State increases 
This is an indicator of changes in the taxpayers self, they have awareness, so they obey their obligations as taxpayers on a regular, orderly and real basis. Therefore, it needs to be socialized optimally, so that the long-term goals of tax amnesty can be achieved according to the target.

\section{BIBLIOGRAPHY}

(1) Abdullah, I., \& Nainggolan, E. P. 2018. Effect of Taxpayer Knowledge, Taxpayer Awareness of Motivation to Pay Taxes With the Implementation of Tax Amnesty Law as Moderating Variable in KANWIL DJP SUMUT I MEDAN. Liabilities Journal of Accounting Education, 1(2), 181-191.

(2) Ajzen, I. 1991. The theory of planned behavior. Organizational behavior and human decision processes, 50(2), $179-211$.

(3) Aladejebi, O. 2018. Measuring Tax Compliance among Small and Medium Enterprises in Nigeria. International Journal of Accounting and Taxation, 6(2), 29-40.

(4) Aji, Angin Prayitno, 2017. Threat of Directorate General of Taxes If Ignore Tax Amnesty,Tempo,Co.Com,Jakarta,March1,2017 http://www.tempo.co.com

Alm, J., Martinez-Vazquez, J., \& Wallace, S. 2009. Do Tax Amnesties work? The Revenue Effects of Tax Amnesties during the Transition in the Russian Federation.

(6) Amalia, M. 2017. Legal Policy Against the Implementation of Tax Amnesty in Improving the Welfare of the Indonesian Nation. The Justitia Law Journal , 3(1), 17-34.

Bamber, E. Michael, "Opportunities in Behavioral Accounting Research", Journal Behavioral Research in Accounting, Volume 5, 1993, University of Georgia, USA.

Bayer, R. C., Oberhofer, H., \& Winner, H. 2015. The occurrence of tax amnesties: Theory and evidence. Journal of Public Economics, 125, 70-82.

Brotodihardjo, R. Santoso, 2012, Introduction to Tax Law, Publisher : Eresco Bandung.

Burrell, Gibson \& Gareth Morgan, 1979, Sociological Paradigms and Organisational Analysisi, Elements of the Sociology of Corporate Life, Ashgatic website http://www.ashgate.com

Chintya Dei A.A., dan Ni Ketut Lely Aryani Merkusiwati, 2013, Analysis of Taxpayer Compliance Levels for Fulfillment of Hotel and Restaurant Tax Obligations in Bandung Regency in 2011 , E-Jurnal Akuntansi Universitas Udayana 4.1. (2013) : $110-127$.

(12) Choiruman, 2004, » Strategy for Improving Compliance », Published on July 4th 2012 , www.dirjenpajak-kementeriankeuangan.

(13) Chua, Wai Fong, Radical Developments in Accounting Thought, October 1986.

The Accounting Review, Vol.LXI, No. 4,

(14) Cresswell, J. W. (2008), Educational Research: Planning Conducting and Evaluating Quantitative and Qualitative Research.

(15) Darmawan, Agus. 2016. Indonesia's Tax Amnesty Law Based On The perspective of The Law As An Allocative System .Yustisia, 5(3).

(16) Darussalam. 2016. Tax Amnesty. in the framework of National Reconciliation Inside Tax, 26: 15-19

(17) Faisal, Mohammad, Post-End of the Tax Amnesty Program, Tempo, Jakarta, 2 April 2017 (http://www. Tempo.co.com). 
International Journal of Advances in Scientific Research and Engineering (ijasre), Vol 5 (5), May-2019

(18) Gay, Mills I... \& Airansian, P. (2006), Educational Reseach : Competencies for Analysis and Application (Vol. 8 th Edition). New York : Prentice Hall.

(19) Gerger, Güneú Çetin. 2012. Tax Amnesties And Tax Compliance In Turkey. International Journal of Multidisciplinary Thought. 2(3), 107-113.

(20) Gudono, 2014, Teori Organisasi, BPFE- Yogyakarta.

(21) Huda, M. K., \& Hernoko, A. Y. 2017. Tax Amnesties in Indonesia and other Countries: Opportunities and challenges. Asian Social Science, 13(7), 52-61.

(22) Husnirrosyidah. 2016. The Influence of Tax Amnesty and Tax Sanctions on Tax Compliance in the BMT of Pati village. EQUILIBRIUM: Journal of Islamic Economics ，4(2), 211-226.

(23) Ibrahim, M. A., Myrna, R., Irawati, I., \& Kristiadi, J. B. 2018. Tax Policy in Indonesian Energy Sectors: An Overview of Tax Amnesty Implementation. International Journal of Energy Economics and Policy, 8(4), 234-236.

(24) Indriantoro, Nur dan Bambang Supomo, 2010, Business Research Methodology (for accounting and management), Publisher : Faculty of Economics and Business, UGM, Yogyakarta.

(25) Istighfarin, N., \& Fidiana, F. 2018. Tax Amnesty from the Perspective of the Tax Community. ACCRUEL: Accounting Journal , 9(2), 142-156.

(26) Jamil, N. A. 2017. Effectiveness of the Application of Tax Amnesty in Indonesia. Academica: Journal of Multidisciplinary Studies, 1(1), 51-65.

(27) Jung, C. G. 2012. Psychology of the Unconscious. Courier Corporation.

(28) Kamayanti, Ari, 2016, Constructive Methodology, Accounting Research Grounding Religiosity, Rumah Peneleh Foundation, Jakarta.

(29) Qualitative Research Methodology of Accounting, Publisher: Rumah Peneleh Foundation , Jakarta.

(30) Kartikaningdyah, E., \& Oktaveny, F. 2018. The Influence of Perception of Tax Amnesty and Taxpayers' Knowledge Related to UU No. 11 of 2016 on Compliance of Corporate Taxpayers. Journal of Accounting, Economics and Business Management, 6(2), 201-212.

(31) Kehman, Dabiel dan Amos Tversky, 1979, "Prospect Theory : An Analysis of Decision Under Risk", pada Behavioral Economics, Jurnal.

(32) Kelman, H.C., Compliance, Identification, and Internationalization, Three of Processes of Attitude Change, Harvard University Conflict Resolution, Vol. 11, No.1, 1956, p. 53

(33) Kirk, Jarome \& Marc L Miller,1986, p. 9, Reliability and Validity in Qualitatitive Research, Vol 1, Beverly Hills : Sage Publication

(34) Klandermans, B. 1984. Mobilization and participation: Social-psychological expansisons of resource mobilization theory. American sociological review, 583-600.

(35) Compilation of Taxation Law, 2015, Publisher: LPPAPSI Accounting Department, Faculty of Economics and Business, Universitas Airlangga.

(36) Koroy, Tri Ramaraya, «Assessing the Success of Balanced Scorecard as a Strategic Performance Measurement System «, Accounting and Investment Journal , Volume 5 Number 2, July 2004, ISSN : 1411 - 6227

(37) Kurniawati, L. (2018). Tax Amnesty attempts to Strengthen the Tax Sector State Revenues. Substansi, 1(2), $238-264$. 
International Journal of Advances in Scientific Research and Engineering (ijasre), Vol 5 (5), May-2019

(38) Kusuma, I. L., \& widyana Dewi, M. (2018). Tax Amnesty Policy: A Review in the Perspective of Deontology Ethics as a Form of Taxpayer's Choice in Implementing Tax Obligations. Journal of Accounting and Taxes, 18(2), $204-214$.

(39) Lesbacq, Karen, 2015, Justice Theories , Nusa Media, Bandung

(40) Lubis, Arfan Ikhlas, 2014, Behavioral Accounting, Salemba Empat, Jakarta

(41) Luitel, H. S. 2014. Is Tax Amnesty a Good Tax Policy?: Evidence from State Tax Amnesty Programs in the United States. Lexington Books.

(42) Mardiasmo. 2011. Taxation (Revised Edition), Yogyakarta,Andi Yogyakarta.

(43) Mahyudin, D. M. 2015. Analysis of Taxpayer Compliance By Applying the e-SPT Program in Reporting VAT Periodical Tax Returns on Bitung Primary Tax Office. EMBA Journal: Journal of Economic, Management, Business and Accounting Research, 3(1).

(44) Maslow A., 1954, Motivation and Personality, New York : Harper \& https://ilmumanajemenindustri.com/pengertian-motivasi-dan-teori-teori-motivasi/11 April 2019

Row.

(45) Mehmet, N. A. R. 2015. The effects of behavioral economics on tax amnesty. International Journal of Economics and Financial Issues, 5(2), 580-589.

(46) Miniard, P. W., \& Cohen, J. B. (1981). An examination of the Fishbein-Ajzen behavioral-intentions model's concepts and measures. Journal of Experimental Social Psychology, 17(3), 309-339.

(47) Mukarromah, Awwaliatul, Suci Nor Aeny dan Retno Megawati. 2016. The Importance of the Role of Tax Amnesty in 2016. Jakarta: Inside Tax Edition 37 March 2016. http://www.ddtc.co.id/ show Pdf. php?type=publication\&file=pub37-InsideTax. pdf. Accessed on April 16, 2017.

(48) Moleong, Lexy J., 2016, Qualitative Research Methodology, Revised Edition , Remaja Rosdakarya, Bandung.

(49) Neuman, W. Lawrence, 2015, Social Research Methodology: Qualitative and Quantitative Approaches. Issue 7, Index , Jakarta.

(50) Ngadiman, Daniel Huslin. 2015. The Effect of Sunset Policy, Tax Amnesty, and Tax Sanctions on Taxpayer Compliance (Empirical Study at Pratama Jakarta Tax Office Kembangan). Accounting Journal , XIX(02), 225-241.

(51) Nowak, Norman D, 1970, Tax Administration in Theory and Practice, Prager, New York.

(52) Okfitasari, A., Meikhati, E., \& Setyaningsih, T. (2017). ADA APA SETELAH TAX AMNESTY?. Jurnal Akuntansi Multiparadigma, 8(3), 511-527.

(53) Regulation of the Minister of Finance of the Republic of Indonesia No. 118 / PMK. 03/2016 About Tax Amnesty

(54) Regulation of the Minister of Finance of the Republic of Indonesia Number 19 / PMK. 08/2016

(55) Director General of Tax Regulation Number Per - 07 / PJ / 2016

(56) Director General of Tax Regulation Number Per - 11 / PJ / 2016

(57) Putra, Alex Mandala. 2012. The Influence Of Taxpayer Compliance And Tax Sanction On Amnesty Tax Participation. South East Asia Journal Contemporary Business, Economics and Law. 16(5), 1-9.

(58) Rahman, 2015, "Effect of Perception on Tax Sanctions", Thesis, Surakarta Universitas.http://program.mm.inmuh.Surakarta 
International Journal of Advances in Scientific Research and Engineering (ijasre), Vol 5 (5), May-2019

(59) Rawls, John, 2011, A Theory of Justice, Translation of Uzair Fauzan and Heru Prasetyo, Yogyakarta, Pustaka Pelajar.

(60) Regimun, Analysis of Tax Amnesty Implementation in Indonesia, 2016, www.kemenkeu.go.id/sites.default/files.

(61) Robert Bogdan, 1975, Participant Observation in Organizational Setting, Syracuse, N.Y. : Syracuse Universuty Oress.

(62) Roberts, Michael L et al, "Debiasing Balanced Scorecard Evaluation"., Journal Behavioral Research in Accounting, Volume 16, 2004, University of Alabama.

(63) Robbins, Stephen P and Timothy A Judge, 2016, Organizational Behavior, Salemba Empat, Third Printing, Jakarta.

(64) Rosdiana, Haula. 2012, Introduction to Tax Science (Policy and Implementation in Indonesia), Jakarta, RajaGrafindo Persada.

(65) Sa'adah, N. 2017. The Tax Amnesty Policy based on Justice Supports Indonesia's investment climate. Legal Problems , 46(2), 182-189.

(66) Said, E. 2017. Tax policy in action: 2016 Tax Amnesty Experience of the Republic of Indonesia. Laws, 6(4), 16.

(67) Saraçoğlu, O. F., \& Çaşkurlu, E. (2011). Tax amnesty with effects and effecting aspects: tax compliance, tax audits and enforcements around; the Turkish case. International journal of business and social science, 2(7), 95-103.

(68) Schmutz, F. 2016. Measuring the Invisible: An Overview of and Outlook for Tax Non-Compliance Estimates and Measurement Methods for Switzerland. Swiss Journal of Economics and Statistics, 152(2), 125-177.

(69) Setyaningsih, Titik, Why Taxpayers Follow Tax Amnesty (Case Study in Solo), Equity Journal of Economics and Finance, Accreditation No.80/DIKTI/Kep/2012. ISSN $1411-0393$.

(70) Siahaan, Marihot Pahala, 2017, Tax Amnesty di Indonesia, Rajawali Pers, Cetakan ke 1, Jakarta

(71) Nasikhudin dalam Simanjuntak dan Mukhlis, 2012, Understand and educate factors that influence tax compliance, Journal,

(72) $\quad$ https://nasikhudinisme.com/tag/pengertian-kepatuhan-pajak/

visited on April 10, 2019

(73) Skinner, B.F. “Operant Conditiong”, Journal, (www.http://wikipedia.com, 28 Mei 2017).

(74) Sudarma, I., \& Darmayasa, I. N. 2017. Does Voluntary Tax Compliance Increase After Granting Tax Amnesty?.

(75) Soobaroyen, T., \& Poorundersing, B. 2008. The effectiveness of management accounting systems: evidence from functional managers in a developing country. Managerial Auditing Journal, 23(2), 187-219.

(76) Circular of the Director General of Taxes Number SE - 30/PJ/2016

(77) Susanto, Herry., 2012, "Building Taxpayer Voluntary Awareness and Concern" Thesis. http://pajak.go.id/sites/default/files/field/image/herry.jpg

(78) Law of the Republic Indonesia Number 11 of 2016 concerning Tax Amnesty, ratified in Jakarta, on 1 July 2016 , by the President of the Republic Indonesia, promulgated in Jakarta on 1 July 2016, by the Minister of Law and Human Rights of the Republic of Indonesia, Published in the State Gazette of the Republic Indonesia of 2016 Number 131

(79) Law of the Republic of Indonesia Number 28 of 2007 concerning General Provisions and Procedures for Taxation

(80) Vroom, 1964, Cognitive Theory of Motivation, https//:www.academia.edu/5761892/Teori_Teori_Motivasi. 
(81) Wardiyanto, B. 2008. Tax Amnesty Policy [The perspective of the sunset policy implementation framework based Law No. 28 of 2007]. Journal of Society for Culture and Politics , 21(4).

(82) Widianti, W., Panjaitan, F., \& Rudi, A. 2018. Analysis of the Effect of Tax Amnesty on Total Revenue and Total Tax Reporting (Case Study in Kpp Pratama Pangkalpinang). STIE- Business \& Financial Accounting Journal IBEK, 13(2), $1-12$.

(83) Winarso, W., \& Panday, R. 2018. Impact Implementation Of Psak 70 Related To Tax Amnesty On Reporting Of The Firm (Case Study On Cv Btari Senja). Jurnal Manajemen Bisnis, 9(1), 25-35.

(84) Willis J.W., Mukhta Jost, Rema Nilakanta (2007). Foundation of Qualitative Research : Intepretive and Critical Approach, California: Sage PublicationInc.

(85) Yin, R.K. 2013. Case Study Research : Design and Methods : Sage Publication

(86) Zain, Mohammad, 2005, Tax Management, Salemba Empat, Jakarta

(87) Zhang, N., Andrighetto, G., Ottone, S., Ponzano, F., \& Steinmo, S. 2016. " Willing to Pay?" Tax Compliance in Britain and Italy: An Experimental Analysis. PloS one, 11(2), e0150277. 